\title{
The Effect of Entrepreneurial Passion and Opportunity Awareness toward the Sustainability of Startup Businesses
}

\author{
Caroline Pratiwi Nawir, Natalia Christiani \\ International Business Management, Universitas Ciputra, \\ Surabaya, Indonesia
}

\begin{abstract}
The number of unemployment rate in Indonesia that has been decreasing is caused by the growth of entrepreneurship in Indonesia, which is proven by the number of startup businesses in Indonesia reaching the sixth highest worldwide. Nevertheless, startup businesses have high failure rate, where two of three established startup businesses cannot sustain. With purpose to find out the reason of this phenomenon, this research aims to find out whether entrepreneurial passion and opportunity awareness have significant effects to startup businesses' sustainability. This research uses the startup businesses of Ciputra University's 2015 batch students that have been running for minimum 2 years as the sample. These startup businesses are aimed to be able to represent startup businesses since from more than 200 startup businesses established, only 42 startup businesses that sustain. Questionnaires are distributed to the samples using 5-points Likert-scale, and the data collected is then analyzed using Multiple Linear Regression. The result shows that entrepreneurial passion has significant effect toward startup business sustainability, but it does not go the same way with opportunity awareness. Opportunity awareness does not affect significantly toward startup business sustainability since it needs to be converted into opportunity recognition and opportunity exploitation to give significant effects.
\end{abstract}

Keywords: entrepreneurial passion, opportunity awareness, business sustainability, startup businesses

\section{Introduction}

The unemployment rate in Indonesia has been decreasing from $8.06 \%$ in 2007 to $4.28 \%$ in 2017. This steep decrease is caused by the growth of entrepreneurship in Indonesia, which is proven by the number of startup business in Indonesia that is the sixth highest worldwide. The same situation is shown by the research conducted by Dilanchiev (2014) showing that entrepreneurship is one of the key solutions of unemployment problem in Georgia since it has a positive effect on job creation. However, even though the number of startups in Indonesia can be considered high and keep increasing, most startups do not follow the linear growth theory

\footnotetext{
*Corresponding Author.
}

e-mail: carolinenawir@gmail.com
(Garney et al., 2006 in Tassinari 2016) and have high rate of failure since less than one third of established startups remain, the rest fail in the very early stages. Davila et al., (2015) found out that these failures are $87 \%$ caused by internal factors, while only $13 \%$ caused by external factors. Therefore, this research more focuses on investigating the internal factors of the startup businesses, which are the entrepreneurs themselves, and the variables chosen to be measured are entrepreneurial passion and opportunity awareness.

Entrepreneurial passion and opportunity awareness are chosen since both of them are internal factors or determined from the entrepreneurs themselves. Entrepreneurial passion is explained by Cardon and colleagues (2009) in Biraglia and Kadile (2016) as positive intense 
Caroline Pratiwi Nawir, Natalia Christiani / The Effect of Entrepreneurial Passion and Opportunity Awareness toward the Sustainability of Startup Businesses / JEE, Vol. 8, No. 1, March 2019, pp. 33-40

feelings to entrepreneurial activities and becomes a powerful motivation for the entrepreneurs. Researcher's assumption is supported by Chebo and Kate (2018), stating that entrepreneurial passion is crucial in the process of creating startups and able to affect its outcomes since it is able to foster creativity and recognition of new information. Moreover, entrepreneurial passion can also help the entrepreneurs to overcome barriers they face in their startups (Biraglia and Kadile, 2016). Besides entrepreneurial passion, researcher also assumes that opportunity awareness is important in entrepreneurship, as being stated by Krueger (2003:105) in Audretesch (2015) that "The heart of entrepreneurship is an orientation toward seeing opportunities”. Audretesch (2015) also explained that one of entrepreneurship literature nowadays focuses on how and why of opportunity discovery, how to discover the opportunity and why some tends to discover more than others.

Based on the phenomenon and theories explained before, it has been shown that both entrepreneurial passion and opportunity awareness play important role in entrepreneurship. It can be seen through the research result of Biraglia and Kadile (2016) showing a strong relationship between entrepreneurial passion and entrepreneurial intention and the explanation by Karimi et al., (2014) that opportunity and business intention are closely connected to each other since opportunity is able to encourage someone to start a new business. Even though it has been clear that both entrepreneurial passion and opportunity awareness are strongly related with business intention, there are still no theoretical proofs directly stating entrepreneurial passion and opportunity awareness have correlation with startup business sustainability. Therefore, this research aims to find out the effect of entrepreneurial passion and opportu- nity awareness toward the sustainability of startup businesses.

\section{Method}

This research uses quantitative approach, since it is "intended to achieve breadth of understanding" (Etikan et al., 2015) or generalization and use numeric data (Landrum and Garza, 2015). While the population for this research is the business projects of Ciputra University students' 2015 batch since it is the oldest batch that currently takes Entrepreneurship class and the only batch whose business projects have been running for more than two years. In determining the sample, this research uses purposive sampling causing the samples have to meet several requirements, which are the CEOs or founders of the business projects and the business projects must have been running for minimum two years. Based on data that have been obtained from Ciputra University's Faculty of Entrepreneurship and Humanities, there are 826 students from 2015 batch with 371 projects, where 100 projects are from family business guild and 50 students whom are in corporate entrepreneurship guild will be excluded, while the rest are in startup business guild. Nevertheless, there are only 81 business projects that might meet the requirements. Since it is still unknown whether these business projects are still running or not, all the samples will be given preliminary questions to make sure the ones that fill out the questionnaire are still running their business projects.

There are two types of data that will be gathered in this research, which are primary data and secondary data. Primary data are got from the result of questionnaires that have been made with 5 -points Likert scale in order to ask the respondents to show their agreement level, 
whether they agree or disagree with the statements, and the data gained was then processed with SPSS 22. While the secondary data are got from literature books and journals.

The research objects for this research are the business projects of Ciputra University students' 2015 batch that have been running for minimum two years. The questionnaire has been distributed to 42 CEOs or founders of the business project, using purposive sampling method.

\section{Results}

Based on the result of item analysis (Tabel 1) that has been conducted, all 13 statements used are valid, since their Pearson Correlation $(r)$ are all above $r$-table (Pearson Product Moment for 42 samples is 0.304 ) and the significance value for every statement is 0.000 (below 0.05). In addition to item analysis, reliability test has also been conducted to make sure that all statements used for each variable are reliable. The result shows that all statements used in the questionnaire are reliable since the result's Cronbach Alpha are all above 0.06 (Tabel 2).

Table 1 Item Analysis

\begin{tabular}{|c|c|c|c|}
\hline Variable & Statement & $\begin{array}{c}\text { Pearson } \\
\text { Correlation }\end{array}$ & Significance \\
\hline \multirow{3}{*}{$\begin{array}{l}\text { Entrepreneurial } \\
\text { Passion }\left(x_{1}\right)\end{array}$} & $y_{1.1}$ & 0.779 & 0.000 \\
\hline & $x_{1.2}$ & 0.788 & 0.000 \\
\hline & $x_{1.3}$ & 0.751 & 0.000 \\
\hline \multirow{5}{*}{$\begin{array}{c}\text { Opportunity } \\
\text { Awareness }\left(x_{2}\right)\end{array}$} & $\underline{x}_{2.1}$ & 0.526 & 0.000 \\
\hline & $\underline{x}_{2.2}$ & 0.753 & 0.000 \\
\hline & $x_{2.3}$ & 0.767 & 0.000 \\
\hline & $x_{2.4}$ & 0.607 & 0.000 \\
\hline & $x_{2.5}$ & 0.547 & 0.000 \\
\hline \multirow{5}{*}{$\begin{array}{c}\text { Business } \\
\text { Sustainability } \\
(y)\end{array}$} & $y_{1.1}$ & 0.627 & 0.000 \\
\hline & $y_{1.2}$ & 0.657 & 0.000 \\
\hline & $y_{1.3}$ & 0.790 & 0.000 \\
\hline & $y_{1.4}$ & 0.623 & 0.000 \\
\hline & $y_{1.5}$ & 0.766 & 0.000 \\
\hline
\end{tabular}

Table 2 Reliability Test Result

\begin{tabular}{|c|c|c|c|}
\hline Variable & Statement & $\begin{array}{c}\text { Cronbach } \\
\text { Alpha }\end{array}$ & Category \\
\hline $\begin{array}{c}\text { Entrepreneurial } \\
\text { Passion }\left(x_{1}\right)\end{array}$ & $\begin{array}{l}x_{1.1} \\
x_{1.2} \\
\end{array}$ & 0.662 & Reliable \\
\hline & \begin{tabular}{|l|}
$x_{1.3}$ \\
$x_{2.1}$
\end{tabular} & & \\
\hline $\begin{array}{c}\text { Opportunity } \\
\text { Awareness }\left(x_{2}\right)\end{array}$ & \begin{tabular}{|l|}
$x_{2.2}$ \\
$x_{2.3}$ \\
$x_{2.4}$ \\
$x_{2.5}$
\end{tabular} & 0.648 & Reliable \\
\hline $\begin{array}{c}\text { Business } \\
\text { Sustainability } \\
(y)\end{array}$ & \begin{tabular}{|l|}
$y_{1.1}$ \\
$y_{1.2}$ \\
$y_{1.3}$ \\
$y_{1.4}$ \\
$y_{1.5}$ \\
\end{tabular} & 0.733 & Reliable \\
\hline
\end{tabular}

Table 3 Multiple Regression Analysis Result

\begin{tabular}{cccc}
\hline Model & \multicolumn{2}{c}{$\begin{array}{c}\text { Unstandardized } \\
\text { Coefficient }\end{array}$} & $\begin{array}{c}\text { Standardized } \\
\text { Coefficient }\end{array}$ \\
\hline & B & $\begin{array}{c}\text { Std. } \\
\text { Error }\end{array}$ & Beta \\
\hline (Constant) & 0.556 & 0.867 & \\
\hline$x_{1}$ & 0.460 & 0.192 & 0.362 \\
\hline$x_{2}$ & 0.316 & 0.195 & 0.245 \\
\hline \multicolumn{2}{c}{ Dependent Variable: Business Sustainability (Y) } \\
\hline
\end{tabular}

The output of Multiple Regression Analysis that is shown in Table.

Classical Assumption Tests include mt 2 and 3

Table 4 Multicollinearity Test Result

\begin{tabular}{cccc}
\hline \multirow{2}{*}{$\begin{array}{c}\text { Independent } \\
\text { Variable }\end{array}$} & \multicolumn{2}{c}{$\begin{array}{c}\text { Collinearity } \\
\text { Statistics }\end{array}$} & Description \\
\cline { 2 - 4 } & Tolerance & VIF & \\
\hline$x_{1}$ & 0.819 & 1.222 & No Multicollinearity \\
\hline$x_{2}$ & 0.819 & 1.222 & No Multicollinearity \\
\hline
\end{tabular}

Table 5 Normality Test Result

\begin{tabular}{cccc}
\hline & \multicolumn{3}{c}{ Kolmogorov-Smirnov } \\
\cline { 2 - 4 } & Statistic & df & Sig. \\
\hline $\begin{array}{c}\text { Unstandardized } \\
\text { Residual }\end{array}$ & .113 & 42 & .200 \\
\hline
\end{tabular}

*. This is a lower bound of the true significance.

a. Liliefors Significance Correction

Table 6 Heteroskedasticity Test Result

\begin{tabular}{cc}
\hline & Sig. \\
\hline Entrepreneurial Passion & 0.414 \\
\hline Opportunity Awareness & 0.126 \\
\hline
\end{tabular}


Caroline Pratiwi Nawir, Natalia Christiani / The Effect of Entrepreneurial Passion and Opportunity Awareness toward the Sustainability of Startup Businesses / JEE, Vol. 8, No. 1, March 2019, pp. 33-40

Table 7 Linearity Test Result

\begin{tabular}{lccc}
\hline Independent Variable & F & $\begin{array}{c}\text { Sig. } \\
\text { Linearity }\end{array}$ & Description \\
\hline $\begin{array}{l}\text { Entrepreneurial } \\
\text { Passion }\end{array}$ & $\underline{10.695}$ & $\underline{0.002}$ & $\begin{array}{c}\text { Linear } \\
\text { Correlation }\end{array}$ \\
\hline $\begin{array}{l}\text { Opportunity } \\
\text { Awareness }\end{array}$ & $\underline{7.278}$ & $\underline{0.011}$ & $\begin{array}{c}\text { Linear } \\
\text { Correlation }\end{array}$ \\
\hline
\end{tabular}

Table 8 F Statistics Test Result

\begin{tabular}{|c|c|c|c|c|c|}
\hline \multicolumn{6}{|c|}{ ANOVA $^{\mathrm{a}}$} \\
\hline Model & $\begin{array}{l}\text { Sum of } \\
\text { Squares }\end{array}$ & $\mathrm{df}$ & $\begin{array}{c}\text { Mean } \\
\text { Square }\end{array}$ & $\mathrm{F}$ & Sig. \\
\hline Regression & 3.441 & 2 & 1.721 & 7.110 & 0.002 \\
\hline$\underline{\text { Residual }}$ & 9.439 & $\underline{39}$ & $\underline{0.242}$ & & \\
\hline Total & $1 \overline{2.8802}$ & $\underline{\overline{41}}$ & & & \\
\hline $\begin{array}{l}\text { a. Depende } \\
\text { b. Predicto } \\
\text { Opportu }\end{array}$ & $\begin{array}{l}\text { Variable } \\
\text { (Constar } \\
\text { ity Aware }\end{array}$ & $\begin{array}{l}\overline{\text { Bus }} \\
\text { : En } \\
\text { less }\end{array}$ & ess Sust & $\begin{array}{l}\text { nabilit } \\
\text { ial Pass }\end{array}$ & \\
\hline
\end{tabular}

The result of Multicollinearity Test shows that the VIF value for both independent variables are below 10, which is 1.222 with tolerance above 0.1 , which is 0.819 . From this data, it can be concluded that there are no multicollinearity between independent variables.

In Normality Test (Tabel 5) the residual significance is 0.200 , which is $>0.05$. From this data, it can be concluded that the independent variables and dependent variable have normal distribution. In Heteroskedasticity Test the significance for entrepreneurial passion and opportunity awareness is 0.414 and 0.216 , which is higher than 0.05. Therefore, it can be concluded that there are no heteroskedasticity in this research. In Linearity Test (Tabel 7) the linearity significance for both entrepreneurial passion and opportunity awareness are below 0.05. Therefore, both entrepreneurial passion and opportunity awareness have linear correlation to business sustainability.

Since the result of F-statistic test (Tabel 8) shows that the F-value (7.110) is higher than Ftable (3.238) and the F-significance value (0.002) is lower than 0.05 , it can be concluded that both entrepreneurial passion and opportunity awareness simultaneously have significant effects toward startup business sustainability.

Table $9 t$ Statistics Test Result

\begin{tabular}{ccc}
\hline$\underline{\text { Model }}$ & $\underline{\mathrm{t}}$ & $\underline{\text { Sig. }}$ \\
\hline$\underline{\text { Constant })}$ & $\underline{0.642}$ & $\underline{0.525}$ \\
\hline$\underline{\boldsymbol{x}_{1}}$ & $\underline{2.392}$ & $\underline{0.022}$ \\
\hline$\underline{\boldsymbol{x}_{2}}$ & $\underline{1.619}$ & $\underline{0.113}$ \\
\hline
\end{tabular}

Dependent Variable: Business Sustainability (Y)

Pertial significance test (Tabel 9) the significance value of entrepreneurial passion $\left(x_{1}\right)$ is 0.022 . Since it is lower than 0.05 , it can be concluded that entrepreneurial passion significantly affects startup business sustainability. The significance value of opportunity awareness $\left(x_{2}\right)$ is 0.113 . Since it is higher than 0.05 , it can be concluded that opportunity awareness does not significantly affect startup business sustainability.

The value of Coefficient of Correlation (Tabel 10) is 0.517 , showing there is a relationship between independent variables and dependent variable. However, the relationship is not strong, but also not weak, since it is in the middle, 0.5 from range 0 to 1 . Besides, the Coefficient of Determination (Tabel 10) is 0.267 or $26.7 \%$, which means that $26.7 \%$ of the dependent variable (startup business sustainability) is determined by the independent variables (entrepreneurial passion and opportunity awareness).

Table 10 Coefficient of Correlation and Determination Test Result

\begin{tabular}{ccccc}
\hline \multicolumn{5}{c}{ Model Summary $^{\mathrm{b}}$} \\
\hline Model & $\mathbf{R}$ & R Square & $\begin{array}{c}\text { Adjusted } \\
\mathbf{R} \\
\text { Square }\end{array}$ & $\begin{array}{c}\text { Std. Error of } \\
\text { the Estimate }\end{array}$ \\
\hline 1 & 0.517 & 0.267 & 0.230 & 0.49195 \\
\hline
\end{tabular}

\footnotetext{
a. Predictors: (Constant), Entrepreneurial Passion, Opportunity Awareness

b. Dependent Variable: Business Sustainability
} 


\section{Discussion}

The result of $t$ statistic test shows that the significance of entrepreneurial passion is 0.022 , which means the entrepreneurial passion has significant effect toward startup business sustainability since its significance is lower than 0.05. Moreover, the regression coefficient of entrepreneurial passion, as shown in Table 4.8, is 0.460 (positive), which means if there is an increase in value of entrepreneurial passion, then the startup business sustainability will also increase. Therefore, the first hypothesis of this research stating "Entrepreneurial passion positively affects startup business sustainability" is accepted.

Previous research by Shrivastava (2010) stated that passion is one of the most crucial factors in determining managerial performance, since with passion, people are able to be more focused and motivated. The effect of entrepreneurial passion toward business sustainability has been proven by many sustainable businesses that were made with passion, one of them is The Body Shop.

The significance of opportunity awareness is 0.113 , which is higher than 0.05 . The result shows that opportunity awareness does not have significant effect toward startup business sustainability. Therefore, the second hypothesis of this research, which is "Opportunity Awareness positively affects startup business sustainability" is rejected.

According to Tang et al., (2012) in Kuckertz (2017), opportunity awareness is having an open mind regarding business opportunities with three dimensions. However, even though the entrepreneurs are able to be aware of the opportunities, there are other affecting factors, such as speed and confidentiality in order to gain advantages of the opportunities
(Alvarez and Barney, 2007 in Welter and Alvarez, 2015), which are then identified by Kuckertz (2017) as opportunity recognition and opportunity exploitation. Kuckertz (2017) defines opportunity recognition as information gathering activities about new products or services after being aware to potential business opportunities (opportunity awareness), while opportunity exploitation is defined as opportunities development activities in order to become a new product or service, such as gathering the information (opportunity recognition). This definition shows that opportunity recognition arises from opportunity awareness, while opportunity exploitation arises from opportunity awareness and opportunity recognition.

According to the result of the research done by Kuckertz (2017), both opportunity recognition and opportunity exploitation have significant association with innovation. While the research by Schaltegger et al., (2016) explains that innovation leads to sustainability in this current dynamic and transforming market. Based on the research results above, it can be concluded that both opportunity recognition and opportunity exploitation have relationship toward business sustainability. Therefore, even though the data shows that opportunity awareness does not have significant association with business sustainability, opportunity awareness is able to affect business sustainability only if the entrepreneurs gather opportunities' information after being aware (opportunity recognition) or developing the opportunities into a new product or service after the recognition (opportunity exploitation).

\section{Conclusion}

Based on the data analysis result and discussion above, it can be concluded that: (1) 
Caroline Pratiwi Nawir, Natalia Christiani / The Effect of Entrepreneurial Passion and Opportunity Awareness toward the Sustainability of Startup Businesses / JEE, Vol. 8, No. 1, March 2019, pp. 33-40

Entrepreneurial passion significantly affects the sustainability of startup businesses, (2) Opportunity awareness does not significantly affect the sustainability of startup businesses.

Therefore, in order to make startup businesses become more sustainable, the entrepreneurs need to increase their entrepreneurial passion by joining business seminars and workshops relating to entrepreneurial passion. While for the working environment, startup businesses can set division of task for each members or employees according to their own passion so they are more motivated and passionate in doing their jobs.

On the other hand, startup businesses should increase not only their opportunity awareness but also opportunity recognition and opportunity exploitation in order to make their business more sustainable. Opportunity recognition and opportunity exploitation should be since they are significantly related to innovation, which leads to business sustainability. Despite, opportunity awareness is still needed since opportunity exploitation arises from opportunity recognition and opportunity recognition arises from opportunity awareness.

From the comprehension and result of this research, there are some suggestions: (1) For entrepreneurs, to understand the effect of entrepreneurial passion and opportunity awareness toward sustainability of startup businesses. Entrepreneurs are suggested to improve their entrepreneurial passion by joining seminars or workshops related to entrepreneurial passion. (2) For further research, to find out whether the opportunity recognition and opportunity exploitation have significant effects toward startup business sustainability using longitudinal data in order to measure the cause and effect relationship.

\section{References}

Audretsch, D.B. 2015. The Knowledge Spillover Theory of Entrepreneurship. The Emergence of Entrepreneurial Economics, pp. 37-54. Retrieved from http://dx.doi.org/ 10.1016/S0737-1071(05)09003-7.

Biraglia, A. \& Kadile, V. 2016. The Role of Entrepreneurial Passion and Creativity in Developing Entrepreneurial Intentions: Insights from American Homebrewers. Journal of Small Business Management, Vol. 55, No. 1, pp. 170-188. doi:10.1111/ jsbm.12242.

Chebo, A.K. and Kute, I.M. 2018. Uncovering the Unseen Passion: A Fire to Foster Ambition Toward Innovation. World Journal of Entrepreneurship, Management, and Sustainable Development. Retrieved from https://doi.org/10.1108/WJEMSD-032017-0013.

Davila, A., Foster, G., He, X., and Shimizu, C. 2015. The Rise and Fall of Startups: Creation and Destruction of Revenue and Jobs by Young Companies. Australian Journal of Management, Vol. 40, No. 1, pp. 6-35. doi:10.1177/0312896214525793.

Dilanchiev, A. 2014. Relationship between Entrepreneurship and Unemployment: The Case of Georgia. Journal of Social Sciences, Vol. 3, No. 2. Retrieved from http://oaji.net/ articles/2016/2903-1455537612.pdf.

Etikan, I. 2016. Comparison of Convenience Sampling and Purposive Sampling. American Journal of Theoretical and Applied Statistics, Vol. 5, No. 1, pp. 1. doi:10. 11648/j.ajtas.20160501.11.

Karimi, S., Biemans, H.J., Lans, T., Chizari, M., \& Mulder, M. 2014. The Impact of Entrepreneurship Education: A 
Study of Iranian Students' Entrepreneurial Intentions and Opportunity Identification. Journal of Small Business Management, Vol. 54, No. 1, pp. 187-209. doi: 10.1111/jsbm.12137.

Kuckertz, A., Kollmann, T., Krell, P., \& Stöckmann, C. 2017. Understanding, Differentiating, and Measuring Opportunity Recognition and Opportunity Exploitation. International Journal of Entrepreneurial Behavior \& Research, Vol. 23, No. 1, pp. 78-97. doi:10.1108/ijebr-12-2015-0290.

Landrum, B., and Garza, G. 2015. Mending Fences: Defining the Domains and Approaches of Quantitative and Qualitative Research. Qualitative Psychology, Vol. 2, No. 2, pp. 199-209. doi:10.1037/qup 0000030.

Mustikarini, C. N. 2017. Factors of Opportunity Awareness in Family Business Successor Generation at Surabaya. International Journal of Academic Research in Business and Social Sciences, Vol. 7, No. 12. doi:10.6007/ijarbss/v7-i12/3742.

Rezaee, Z. 2016. Business Sustainability Research: A Theoretical and Integrated Per- spective. Journal of Accounting Literature, Vol. 36, pp. 48-64. doi:10.1016/j.acclit. 2016.05 .003

Schaltegger, S., Lüdeke-Freund, F., \& Hansen, E.G. 2016. Business Models for Sustainability. Organization \& Environment, 29(3), 264-289. doi:10.1177/10860 26616633272.

Shrivastava, P. 2010. Pedagogy of Passion for Sustainability. Academy of Management Learning \& Education, Vol. 9 No. 3, pp. 443-455. doi:10.5465/amle.2010.53791 826.

Tassinari, L. 2016. Sustainability of Startups in Australia: a Policy-Maker Perspective (Master's thesis).

Tonello, M. \& Singer, T. 2015. The Business Case for Corporate Investment in ESG Practices. Retrieved from https://www. conference-board.org/publications/publicationdetail.cfm? publicationid $=2996$.

Welter, C., and Alvarez, S. 2015. The State of Opportunities: Clarifying the Transitions between Opportunity Types. Management Decision, Vol. 53, No. 7, pp. 1398-1411. doi:10.1108/md-07-2014-0466. 
Caroline Pratiwi Nawir, Natalia Christiani / The Effect of Entrepreneurial Passion and Opportunity Awareness toward the Sustainability of Startup Businesses / JEE, Vol. 8, No. 1, March 2019, pp. 33-40 